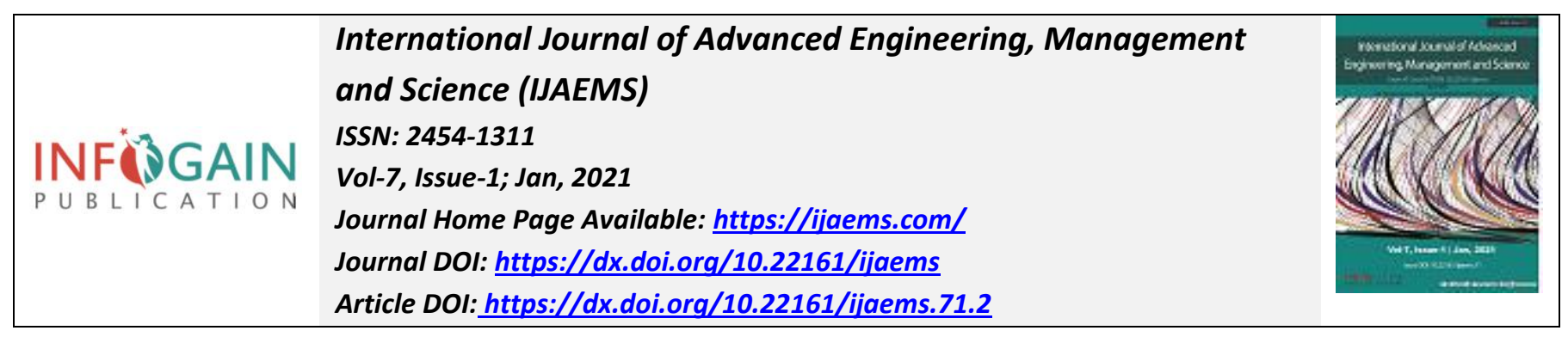

\title{
Effectiveness and Acceptability of Instructional Materials in the Enhancement of Students' Academic Achievement
}

\author{
Hernan V. Portana, Jennifer G. Fronda, Divina Grace T. Policarpio, Krishia Anne Rome C. \\ Rigat, Gemdexter A. Llames
}

Nueva Ecija University of Science and Technology, Cabanatuan City, Philippines

Received: 27 Nov 2020; Received in revised form: 25 Dec 2020; Accepted: 02 Jan 2021; Available online: 07 Jan 2021

C2021 The Author(s). Published by Infogain Publication. This is an open access article under the CC BY license

(https://creativecommons.org/licenses/by/4.0/).

\begin{abstract}
The study examined the effectiveness and acceptability of the instructional materials developed by the faculty of the College of Management and Business Technology (CMBT) of the Nueva Ecija University of Science and Technology (NEUST). The sample consisted of selected instructional materials developed by the said Department. This included the instructional materials being used by the Master of Business Administration and Doctor of Philosophy in Business Administration of the Graduate School. The research employed the descriptive design where eighty-eight respondents were purposively selected. The parameters in the instrument used were the instructional content, procedure, relevance, knowledge and practical applications, clarity, development of higher thinking skills, and alignment with the thrusts and goals and objectives of the University. The following findings were made: the total weighted mean got 3.55 with verbal description of "Very Satisfactory" indicated that the instructional materials developed by CMBT faculty were acceptable, except for the item friendliness of figures which got a "Needs Improvement" rating. Recommendations for the enhancement and continuous development of instructional materials were also made
\end{abstract}

Keywords-instructional materials effectiveness, higher thinking skills, curriculum, syllabus.

\section{INTRODUCTION}

Instructional materials are encouraged to be developed especially in State Universities and Colleges (SUCs). Not all books or reference materials in a particular subject can be available in bookstores. In fact, they can be too costly and mostly authored by foreigners devoid of Philippine setting; current practices and trends are foreign in nature. However, thedeveloped instructional materialsshould be tested for its effectiveness. There are several parameters to be considered in knowing the developed instructional materials acceptable not only to the learners' use, but also on the part of the educators. . Its content, readability, and references are some of the factors to be consideration to make it effective. According to Kenobi Krukru, the use of instructional materials help facilitate and enhance effective teaching and learning. Theuses of instructional materials arevaried that can support students increase their knowledge and better understandingof the subject content.

Instructional materials provide various ways and strategies to make easy and comfortable the teaching and learning processes because it constitutes tangible contents so even the learners can easily understand and be connected to 
the subject. Because of the many advantages it brings, most educators find systematic ways in understanding the individual differences especially the learners in whole teaching processes.

According to Onyedikachi (2011) as cited in the study of Oden (n.d), teaching without tools is impossible to attain the teaching and learninggoals and competency. The instructional tools make possible a better understanding on the subject to make students learn from themselves. Furthermore, in the study of Ezekoka (2008), revealed that developed instructional materials served as an important components in the teaching and learning delivery modalities that carries all important messages, data andinformation from a transmitting source(teachers)to the receiver (learner).

Effective instructional materials are designed to instigate, ignite and bring desirable changes in the students' learning abilities, attitude and behavior in more interesting and meaningful classroom settings.

Onasanwa and Omosewo (2011) discussed instructional materials as a key component that may be used in teaching and learning process that can disseminate information, data, idea and messages that could help learners enhance their academic achievements.

Specifically, instructional tools like developed materials is one of the tools that can help teachers convey knowledge in a very natural way leading to good teaching and learning processes (Koko, 2015).

In the study of Soetan et.al (2010), they particularly stated that graphics, poster, cartoon sketches and drawings, graphs found in developed instructional materials help learners increase their level of understanding and could help them communicate facts and idea clearly. It also helps learners to visualize the concepts learned and its relationship to others.

Generally, developed instructional materials can be classified as primary and secondary aids and outlines used in effective teaching and learning. Hence, it is the ability of the teachers to identify the quality and appropriateness upon utilizing the developed instruction materials. And on students' part, instructional materials may guide them to acquire more information so as to bring the learners much appreciation on the topics under consideration.

To this notion, the researcher aimto determine theeffectiveness andthe level of acceptability of theinstructional materials developed by the CMBT faculty.

\section{OBJECTIVES OF THE STUDY}

The study aimed to determine the effectiveness of the developed instructional materials developed by College of Management and Business Technology (CMBT) faculty of NEUST.

The study aimed to answer the following:

1. Describe the parameters used in testingthe acceptability of the instructional materials in terms ofcontent, understanding procedure knowledge and application, practical applications inits relevance, clarity of timely information, alignment to the thrust of the University, friendliness of the figuresand development ofHigher Order Thinking Skills (HOTS).

2. Describe the challenges encountered by the teachers in using the developed instructional materials in teaching and the students' learning process

\section{Propose an enhancement plan}

\section{RESEARCH METHOD}

The researcher used the descriptive research design involving 88 CMBT, MBA, and Ph.D. - Business Administration students were selected using purposive sampling. The questionnaire consisted of Likert scale with verbal description of "Excellent", "Very Satisfactory", "Satisfactory", "Needs Improvement" and "Poor" as choices. The same way that the equivalent description to be "Very Effective", "Effective", "Moderately Effective", "Slightly Effective", and "Not Effective". The instrument was distributed before the end of the semester who used the books or instructional materials.

Range of scores and its verbal interpretation is shown below:

Table 1. Range and Verbal Interpretation Equivalent

\begin{tabular}{|c|c|c|c|}
\hline Point & Range & Verbal Analogy & $\begin{array}{c}\text { Effectiveness } \\
\text { Verbal Equivalent }\end{array}$ \\
\hline 5 & $4.21-5.00$ & Excellent & Very Effective \\
\hline 4 & $3.41-4.20$ & Very Satisfactory & Effective \\
\hline 3 & $2.61-3.40$ & Satisfactory & $\begin{array}{c}\text { Moderately } \\
\text { effective }\end{array}$ \\
\hline 2 & $1.81-2.60$ & $\begin{array}{c}\text { Needs } \\
\text { improvement }\end{array}$ & $\begin{array}{c}\text { Slightly effective } \\
\text { Poor }\end{array}$ \\
\hline
\end{tabular}




\section{RESULTS AND DISCUSSION}

1. Descriptions of parameters used in testing the acceptability of the instructional materials in terms of content, understanding procedure, knowledge and application, practical applications and its relevance, clarity of timely information, alignment to the thrusts of the University, friendliness of the figures, and development of higher order thinking skills.

Table 2. Description of the Parameters Used in Instructional Materials

\begin{tabular}{|l|c|l|}
\hline \multicolumn{1}{|c|}{ Description } & $\begin{array}{c}\text { Weighted } \\
\text { Mean }\end{array}$ & \multicolumn{1}{c|}{$\begin{array}{c}\text { Verbal } \\
\text { Description }\end{array}$} \\
\hline Content & 3.74 & Very Satisfactory \\
\hline $\begin{array}{l}\text { Understanding } \\
\text { procedure, } \\
\text { knowledge and } \\
\text { application }\end{array}$ & 3.38 & Satisfactory \\
\hline $\begin{array}{l}\text { Practical } \\
\text { applications in its } \\
\text { relevance }\end{array}$ & 3.84 & Very Satisfactory \\
\hline $\begin{array}{l}\text { Clarity of timely } \\
\text { information, }\end{array}$ & 3.46 & Very Satisfactory \\
\hline $\begin{array}{l}\text { Alignment to the } \\
\text { thrusts of the } \\
\text { University }\end{array}$ & 3.75 & Very Satisfactory \\
\hline $\begin{array}{l}\text { Friendliness of the } \\
\text { figures }\end{array}$ & 2.49 & $\begin{array}{l}\text { Needs } \\
\text { Improvement }\end{array}$ \\
\hline $\begin{array}{l}\text { Development of } \\
\text { higher order } \\
\text { thinking skills }\end{array}$ & 4.17 & Very Satisfactory \\
\hline $\begin{array}{l}\text { Overall Weighted } \\
\text { Mean }\end{array}$ & $\mathbf{3 . 5 5}$ & $\begin{array}{l}\text { Very } \\
\text { Satisfactory }\end{array}$ \\
\hline
\end{tabular}

Table 2 shows the summary and tallied results of the survey got an overall weighted mean of 3.55 with verbal description of "Very Satisfactory". The development of higher order thinking skills got 4.17 which is considered the highest among others and friendliness of the figures got the lowest weighted of 2.49 and interpreted as "Needs Improvement".

The results indicate that instructional materials developed by CMBT faculty were acceptable in terms of content, understanding procedure knowledge and application, practical applications, clarity, alignment and development of higher order thinking skills except for the friendliness of figures. The lowest weighted mean for this description is primarily because the cost of using glossy papers for printing are rather expensive, hence not economical, and becomes expensive on the part of the students. Imposing in print color pictures can entail different technique in the printing press which may require specialized machines. On the Item understanding procedure, knowledge and application got a score of only "Satisfactory" that can indicate that the students found difficulty in comprehending the instructions. This connotes a further improvement once the instructional materials are edited.

2. Challenges encountered (Abelardo, et.al, 2019) from using developed instructional materials in the teaching and learning process.

Teachers and even the learners are challenged in using developed instructional materials perhaps due to the following reasons (1) some of instructional materials may be inadequate in both quality and quantity (2) limited topics based on syllabus requirements (3) some of the instructional materials may have complex activities, and (4) unappealing illustrations and figures.

\section{Proposed enhancement plan}

The researchers may propose an enhancement plan for the continuous improvement and development of instructional materials, specifically the friendliness of the illustrations and figures found in the instructional materials.

\section{CONCLUSION AND RECOMMENDATIONS}

Conclusion

The following conclusions are drawn:

a. The instructional materials developed by the CMBT faculty got the total weighted mean of 3.55 with verbal description of "Very Satisfactory". The result means that instructional materials were acceptable as a teaching and learning materials.

b. All of the respondents were challenged on the illustrations and figures used in the instructional materials (Subia, 2020).

\section{Recommendations}

a. Collaboration and brainstorming may help teachers in improving more the instructional materials.

b. The administration may fund the trainings and seminar workshops purposely for instructional materials development and give incentives to authors for motivation and job satisfaction (Bautista \& Balaria, 2018). 


\section{REFERENCES}

[1] Abelardo, L., Lomboy, M., Lopez, C., Balaria, F., \& Subia, G. (2019). Challenges Encountered by the National High School Teachers in Doing Action Research. International Journal of English, Literature and Social Science (IJELS) Vol-4, Issue-4, Jul $\quad-\quad$ Aug 2019 https://dx.doi.org/10.22161/ijels.4418 ISSN:2456-7620.

[2] Alice, O. (2012). Challenges facingthe teachers and students in the of instructional technologies: A case of selected secondary schools in KISII Country, Kenya. Retrieved from:https://ir-

library.ku.ac.ke/bitstream/handle/123456789/6532/Omariba\% 20Alice.pdf?sequence $=3$

[3] Bautista, A. \& Balaria, F. (2018).Work Motivation and Job Satisfaction of Employees before and after Company Reorganization: A Case of an Electric Cooperative in the Philippines. International Journal of Advanced Engineering, Management and Science(ISSN: 2454-1311),4(12), 800-804. http://dx.doi.org/10.22161/ijaems.4.12.3

[4] Ezekoka, M. A. (2008).Teaching Materials and Students AcademicAchievements.Proceedings of the $43^{\text {rd }}$ Annual Conference of STA 7-416-419. Ibadan:Heinemann

[5] Koko, M.N. (2016). The Effective Use of School Instructional Materials. Retrieved from: file:///C:/Users/ITZ\%20SHAR/Downloads/THEEFFECTIVE USEOFSCHOOLINSTRUCTIONALMATERIALSAutosave d.pdf

[6] Koko, M.N. (2015). Teaching Business. Port Harcourt, Nigeria: Harvey Publication Company.

[7] Oden, C. (n.d). The Effectiveness of Instructional Materials in Teaching and Learning of Biology in Senior Secondary School. Retrieved from: https://www.projecttopics.org/effectiveness-instructionalmaterials-teaching-learning-biology-senior-secondaryschool.html

[8] Onasanya, S.A. and Omosewo, E.O. (2011). Effect of improvised and standard instructional materials on Secondary School Students' Academic Performance in Physics in Ilorin, Nigeria. Retrieved from: https://scialert.net/fulltext/?doi=sjsres.2011.68.76

[9] Soetan, A.K., Iwokwagh, N.S., R.A. Shehu, and Onasanya, S.A. (2010). Creating engaging 3-D animation digitization for instructional media and communication. Inform.Technol. J., 9: 89-97.

[10] Subia, G. S. (2020). Fortuitous: A proposed activitybasedbook in mathematics of chance. International Journal of Scientificand Technology Research, 9(3), 450-453. 